\section{Bouncing molecules}

Chemical Applications of Molecular Beam Scattering. By M. A. Fluendy and K. P. Lawley. Pp. xi +400. (Studies in Chemical Physics.) (Chapman and Hall: London; distributed in the USA by Halsted Press, 1973.) £8.

THIs book is to be welcomed as the first non-specialist account of a challenging new field of chemical physics: the direct investigation of binary collision processes by the molecular beam technique. The authors discuss the design, performance and interpretation of the experiments, and also give an outline discussion of the background theory. The coverage reflects the present development of the field with major emphasis on elastic scattering and reactive processes.

The strongest chapters are those which deal with the technical design of the apparatus and with the analysis of elastic scattering experiments. Of these the sections of molecular beam sources, energy and state selection and detection and measurement will be of interest to a wide range of experimentalists. Readers with a more theoretical bias will be attracted by the clear account of quantal interference phenomena, seen not as abstract effects, but as sources of additional information in establishing the relation between the elastic scattering crosssections and the intermolecular force field. The discussion of reactive scattering is equally complete in relation to present understanding, but the intrusion of mathematical detail makes it less easy to follow a clearly defined line of argument. Nevertheless there are few such comprehensive introductions in the literature. I only wish that the bibliography, which covers the important experimental work published before May 1972, could have been extended to include more recent studies on non-alkali atom systems, and that the tables could have contained a fuller resumé of available experimental information.

The level is that of the graduate student, since few undergraduates will have the necessary mathematical background. As such the book will be a wclcome addition to the shelves of every serious chemical physics library.

$$
\text { M. S. CHILD }
$$

\section{A cool look at doom}

Man's Responsibility for Nature: Ecological Problems and Western Traditions. By John Passmore. Pp. $\mathrm{x}+213$. (Duckworth: London, April 1974.) $£ 5.95$ cloth; $£ 1.95$ paper.

THE so-called 'environmental crisis' has been treated by scientists, economists and theologians, at levels ranging from clinical objectivity to crude polemics; and it has been exploited by journalists and television producers. It is now the turn of philosophers; Professor Passmore's book is doubtless the first of a shelf-load of philosophical reflections on doom. It sets a very high standard in erudition, accuracy and clarity. The book opens with a masterly summary of the history of man's attitude to nature. Passmore is slightly apologetic about including this; he assures any anti-historical readers that they can, if they wish, skip it and go straight on to the second part of the book, dealing with ecological problems. In fact the historical essay is the best part of the book, and the only part with anything new to say. It describes vividly the Judaeo-Christian attitude to man, which divides him from other living things and makes him unique by investing him with a soul. This anthropocentric tradition has been blamed for man's exploitation of nature and it has prompted some writers to suggest that Western societies will not show proper concern for the environment unless they adopt a new ethic or a new religion, perhaps borrowed from the East.

Passmore argues powerfully and persuasively against this attitude, and especially against the implication that a scientific and rational attitude to nature cannot be reconciled with concern for the environment. The business of science, he says, is to turn mysteries into problems; only then can one set about trying to solve them. It was Descartes and Bacon, not the author of Genesis, who propagated the view that man can do as he pleases to nature with impunity. But there is no guidance to be found in the views of some contemporary theologians either; Passmore rejects Bishop Montefiore's idea of stewardship and Teilhard de Chardin's idea of cooperation with nature. He has no use for the arcadian musings of Blueprint for Survival. He realises that intellectuals like himself would be the first people to suffer if society were to discard some of the conveniences of modern technological society, such as air travel and motor cars.

From his historical summary Passmore turns to the contemporary ecological problems, which he distinguishes from "problems in ecology": the latter are scientific; the former are social. $\mathrm{He}$ covers familiar ground, reminding his readers (though it is superfluous for anyone likely to read this book) that ecological problems have three components: scientific, economic and ethical; and he brings the reader to the familiar conclusion: that the solution to ecological problems must be politically feasible. It is at this point that the reflections of a philosopher might be expected to illuminate the issues. Unfortunately (but not surprisingly) Passmore's lucid analysis, like that of so many other writers, comes to a stop. We know that some ecological problems (such as pollution) can be solved within the framework of Western democratic institutions. We suspect that others (such as the dedication to everincreasing material consumption) cannot. Before political decisions can be made an ethical question has to be answered: What duty, if any, do we have to posterity? If we cannot make sacrifices to ameliorate the human condition in the third world, which we have seen, is it likely that we shall make sacrifices to ameliorate the human condition of our great-grandchildren, whom most of us will never see?

Passmore seems to have a vague and tentative belief that this ethical question is soluble by rational thought in the framework of Western democratic institutions; perhaps by acting with concern for our offspring and expecting that they will act with equal concern for their offspring. It is a very modest conclusion to a very sophisticated essay. But Passmore is right to be modest. Heroics and utopias are the opiate of environmentalists. We can hope to proceed only through what William Blake called "Minute Particulars" E. AsHBY

\section{Defects in oxides}

Oxide Semiconductors. By Z, M. Jarzebski. Translated from the Polish by B. Grzybowska-Swierkosz. Translation edited by Brian Randall Pamplin. Pp. xi+285. (Pergamon: Oxford and New York; Wydawnictwa NaukowoTechniczne; Warsaw, January 1974.) £6.

THIS is a translation of a treatise by a member of the Warsaw Research Centre for crystals and its title is misleadingly broad. It is writen by an oxide physicist for oxide physicists and concentrates on the transport of carriers in these materials as influenced by defects. It certainly does not attempt to teach, although an early chapter, on preparation techniques for oxides, provides a useful survey of one aspect of oxide technology. The main interest of the author is the effect on the conductivity of oxides produced by heating them at various pressures of oxygen; the last half of the book is a survey of such effects in about ten metal oxides. The data on carrier transport are exhaustively reviewed but the physical mechanisms involved in this transport are referred to in a rather passing manner and certainly not treated at any depth.

The physics of the structure of defects in the oxides is avoided in a 